\title{
Efficacy and safety of once-daily glycopyrronium in predominantly Chinese patients with moderate-to-severe chronic obstructive pulmonary disease: the GLOW7 study [Corrigendum]
}

\section{Wang C, Sun T, Huang Y, et al. Int J Chron Obstruct Pulmon}

Dis. 2015;10:57-68.

The phone number for the corresponding author Chen Wang should be +86 1084206166 .

The International Journal of COPD is an international, peer-reviewed journal of therapeutics and pharmacology focusing on concise rapid reporting of clinical studies and reviews in COPD. Special focus is given to the pathophysiological processes underlying the disease, intervention programs, patient focused education, and self management protocols.
This journal is indexed on PubMed Central, MedLine and CAS. The manuscript management system is completely online and includes a very quick and fair peer-review system, which is all easy to use. Visit $\mathrm{http}: / /$ www.dovepress.com/testimonials.php to read real quotes from published authors. 